\title{
nature
}

\section{Taking a stand on animal-rights violence}

\author{
Governments must not turn a blind eye to intimidation and violence by animal-rights activists. A more \\ resilient approach is needed.
}

\rceil wo months ago, the New York Stock Exchange (NYSE) was set to list the shares of Huntingdon Life Sciences (HLS), a British research company whose bankers and advisers have been constantly hounded by animal-rights activists. When the NYSE announced at the last minute that the listing had been shelved, HLS executives weren't the only ones to be dismayed.

At a hearing of the US Senate Committee on Environment and Public Works last week, the NYSE failed to shed much light on the reasons for the withdrawal. Senators James Inhofe (Republican, Oklahoma) and Frank Lautenberg (Democrat, New Jersey) expressed exasperation that a major national institution could leave itself exposed to allegations that it folded in the face of intimidation.

The committee is supporting legislation that would close several loopholes in an existing law that was designed to protect animal researchers. The changes would, among other things, make it easier to prosecute those who encourage violent attacks on employees of companies that don't do animal research themselves, but have business links with firms, such as HLS, that do.

This legislative approach is likely to prove more fruitful than the aggressive pursuit of precisely what happened when the NYSE pulled the plug on the listing. Inhofe had previously written to the exchange and begged it to show some moral backbone. "It seems to me unimaginable that this country's worldwide symbol of the integrity of the capital markets, the NYSE, would capitulate to threats, or even the mere threat of threats, from a single-issue extremist group," the senator said last week. "Appeasing these groups only validates the effectiveness of their tactics and inspires them to replicate this model of activism in some other venue."

Few would disagree with that, and it is appropriate that the Senate committee should try to shed light on a decision that has received very little play in the US press.

HLS is understandably frustrated. Its lawyer, Mark Bibi, described the NYSE's decision as "perhaps the most shameful apparent capitulation to date". He added that the company has received no feedback from the NYSE about the reasons for it - which the NYSE says are confidential - or about any information that HLS could now provide to help it secure a listing.

But the inclination to blame NYSE and its president, Catherine Kinney - who withdrew from testifying before the Senate, letting her top lawyer take the heat instead - should be resisted. Like other clients and advisers who have shunned HLS, in both Britain and the United States, the NYSE is in a tough position, having had its own staff threatened on the Internet and elsewhere.

Even so, the public mood in the United States could support a more resilient stance by the NYSE and other institutions. There is less latent sympathy for animal-rights activists than in Britain, and more appetite for a vigorous clampdown on their "In the United States there is less latent sympathy for animal-rights activists than in Britain, and more appetite for a clampdown on their criminal activities." criminal activities. Inhofe and Lautenberg should be applauded for their robust public stance on this issue. It contrasts with an occasional tendency in the United States to wish away hundreds of documented instances of animal-rights-related violence.

But the issue isn't going away. The intellectual leadership of the animal-rights movement is shifting to the United States, and the committee took testimony from Jerry Vlasak, a California-based surgeon, who dedined to repudiate previous statements defending violence, and even murder, against researchers. Again, the senators did well to confront the thinking behind animal-rights violence. The committee is now pursuing legal remedies. There is some public fatigue with new laws specific to the motivation of particular crimes, but in this case such laws are needed. Animal-rights activists are exploiting loopholes that, for example, prevent the use of extortion law unless the extorter seeks personal gain. British laws specifically designed to protect animal research were introduced this summer and have had a positive effect. Scientists and national institutions must stand united against animal-rights violence, and legislators should support them by passing Inhofe's proposal.

\section{Turkey's evolution}

\section{Admission to the European Union can benefit Turkish science.}

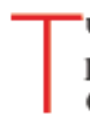
urkey is engaged in negotiations for membership of the European Union (EU), and the first such talks, which opened on 18 October, were centred on science and technology. But they took place at a time when many Turkish scientists are at loggerheads with their government, led by the mildly Islamic Justice and Development
Party. They say the government is, by stealth, allowing Islamic influences to infiltrate the constitutionally secular academic system.

When the Turkish Republic was founded by national hero Kemal Atatürk in 1923, it could boast only a few dozen trained physicians and engineers. Its citizens were dirt-poor, and education available to but a few. This legacy of the sultan-caliphs was put into sharp reverse by Atatürk. His modernization programme was unmistakably Western, and could almost have been conceived with membership of the EU in mind.

He changed the alphabet to Latin script that would be readable by Europeans. He introduced education for all, forcing the literacy rate 